\title{
Inhibitory and Facilitatory Effects of Steroids on the Release of Luteinizing Hormone in the Rat
}

\author{
FUMIHIKO KOBAYASHI, KATSUMI HARA AND TAMOTSU MIYAKE \\ Shionogi Research Laboratory, Shionogi \& Co., Ltd., \\ Fukushima-ku, Osaka
}

\begin{abstract}
Synopsis
A single subcutaneous injection of progesterone $(5 \mathrm{mg} / \mathrm{rat})$, chlormadinone acetate (CMA, $17 \alpha$-acetoxy-6-chloro-pregna-4,6-diene-3,20-dione; $5 \mathrm{mg} / \mathrm{rat}$ ), medroxyprogesterone acetate (MAP, $17 \alpha$-acetoxy- $6 \alpha$-methyl-pregn-4-ene-3,20-dione; $0.5 \mathrm{mg} / \mathrm{rat}$ ) or norethindrone ( $17 \alpha$-ethynyl-17 $\beta$-hydroxyestr-4-en-3-one; $0.5 \mathrm{mg} / \mathrm{rat})$ into 4 -day cyclic rats at 11 a.m. on the 2 nd day of diestrus inhibited spontaneous ovulation on the day corresponding to the following estrus. Also, oral administration of CMA or MAP inhibited ovulation completely at the dosage of $5 \mathrm{mg}$ per rat, whereas norethindrone given in the similar manner did not exhibit the same effect. No inhibition of ovulation was observed in the rats to which norethynodrel $(17 \alpha$-ethynyl-17 $\beta$-hydroxyestr-5(10)en-3-one) had been given either by subcutaneous or by oral route at the dosages up to $10 \mathrm{mg}$ per rat. Of the other steroids tested, androgen was the only one that inhibited spontaneous ovulation. Progesterone, MAP, CMA and norethindrone, administered at the dosage of $10 \mathrm{mg}$ per rat $50 \mathrm{hrs}$. after the initial progesterone treatment, restored ovulation in $24 \mathrm{hrs}$., which had been expected to be delayed with $3 \mathrm{mg}$ of progesterone given at $11 \mathrm{a} . \mathrm{m}$. on the $2 \mathrm{nd}$ day of diestrus. These results indicate that synthetic progestins as well as progesterone have a biphasic action, inhibitory and facilitatory, on the neural mechanism(s) regulating the release of luteinizing hormone in the rat.
\end{abstract}

Our previous work (Kobayashi et al., 1969) elucidated that a single subcutaneous injection of progesterone into 4-day cyclic rats at 11 a.m. on the 2nd day of diestrus (diestrus II) inhibited spontaneous ovulation on the day of expected estrus and caused an approximately 48-hr. delay in ovulation. This delayed ovulation was restored in $24 \mathrm{hr}$. either by estrogen given $24 \mathrm{hr}$. after the progesterone treatment or by the additional progesterone administered during the period of 48 to $54 \mathrm{hr}$. after the initial treatment with progesterone in diestrus II. This communication deals with the inhibitory and facilitatory actions of several steroids, particularly the typical synthetic progestins, on the spontaneous ovulation and on the delayed ovulation caused by progesterone in the rat.

Received for publication September 7, 1969.

\section{Materials and Methods}

Adult female rats of our inbred Wistar strain weighing approximately $200 \mathrm{~g}$ were kept in an airconditioned room with a controlled lighting regimen, 12-hr. lighting from $8 \mathrm{a} . \mathrm{m}$. to $8 \mathrm{p} . \mathrm{m}$. The stage of estrous cycle was determined by checking vaginal smears every morning between 10 and 11 a.m. and the rats exhibiting a regular 4-day estrous cycle were selected for use after confirming at least two normal cycles. Test compounds were dissolved or suspended in sesame oil for subcutaneous injection, whereas the suspending vehicle, consisted of sodium chloride $(0.9 \%)$, polysorbate $80(0.4 \%)$, carboxymethylcellulose $(0.5 \%)$, and benzyl alcohol $(0.9 \%)$, was used for oral administration of the compounds.

Ovulation inhibiting activities of various steroids were tested by the method reported previously (Kobayashi et al., 1969). The test compound was administered subcutaneously or orally at 11 a.m. diestrus II and the occurrence of ovulation, which could be identified by the inspecting of the ova in the dilated ampullae of the oviducts (Kobayashi and Miyake, 1960), was checked about 11 a.m. on the 
Table 1. Effects of progestational steroids on the spontaneous ovulation in rats (subcutaneous assay)

\begin{tabular}{|c|c|c|c|}
\hline Compound* & $\begin{array}{l}\text { Dose } \\
(\mathrm{mg})\end{array}$ & $\frac{\text { No. of rats ovulated }}{\text { No. of rats used }}$ & $\begin{array}{c}\text { Aver. No. of ovulation } \\
\text { per rat }\end{array}$ \\
\hline Sesame oil (control) & - & $5 / 5$ & 9.0 \\
\hline Progesterone & $\begin{array}{l}0.05 \\
0.5 \\
5.0\end{array}$ & $\begin{array}{l}5 / 5 \\
2 / 5 \\
0 / 5\end{array}$ & $\begin{array}{r}9.6 \\
4.4 \\
0\end{array}$ \\
\hline C M A & $\begin{array}{l}0.05 \\
0.5 \\
5.0\end{array}$ & $\begin{array}{l}5 / 5 \\
3 / 5 \\
0 / 5\end{array}$ & $\begin{array}{r}10.4 \\
7.4 \\
0\end{array}$ \\
\hline M A P & $\begin{array}{l}0.05 \\
0.5 \\
5.0\end{array}$ & $\begin{array}{l}2 / 5 \\
0 / 5 \\
0 / 5\end{array}$ & $\begin{array}{r}5.2 \\
0 \\
0\end{array}$ \\
\hline Norethindrone & $\begin{array}{l}0.05 \\
0.5 \\
5.0\end{array}$ & $\begin{array}{l}3 / 5 \\
0 / 5 \\
0 / 5\end{array}$ & $\begin{array}{r}7.8 \\
0 \\
0\end{array}$ \\
\hline Norethynodrel & $\begin{array}{l}0.05 \\
0.5 \\
5.0\end{array}$ & $\begin{array}{l}5 / 5 \\
5 / 5 \\
4 / 4\end{array}$ & $\begin{array}{r}10.4 \\
10.6 \\
9.0\end{array}$ \\
\hline
\end{tabular}

* Each of the compounds tested was administered to the rats at 11 a.m. diestrus II.

CMA : Chlormadinone acetate

MAP : Medroxyprogesterone acetate

Table 2. Effects of progestational steroids on the spontaneous ovulation in rats (oral assay)

\begin{tabular}{lccc}
\hline \hline Compound & $\begin{array}{c}\text { Dose } \\
(\mathrm{mg})\end{array}$ & No. of rats ovulated & $\begin{array}{c}\text { Aver. No. of ovulation } \\
\text { per rat }\end{array}$ \\
\cline { 3 - 4 } Suspending vehicle (control) & - & $5 / 5$ & 10.6 \\
Progesterone & 5.0 & $4 / 5$ & 9.2 \\
& 10.0 & $4 / 5$ & 9.8 \\
C M A & 0.5 & $5 / 5$ & 11.8 \\
& 5.0 & $0 / 5$ & 0 \\
M A P & 0.05 & $5 / 5$ & 11.8 \\
& 0.5 & $1 / 5$ & 3.0 \\
Norethindrone & 5.0 & $0 / 5$ & 0 \\
& 0.5 & $5 / 5$ & 12.4 \\
Norethynodrel & 5.0 & $5 / 5$ & 12.6 \\
& 10.0 & $5 / 5$ & 13.6 \\
& 0.5 & $5 / 5$ & 11.2 \\
& 5.0 & $5 / 5$ & 12.8 \\
\hline
\end{tabular}

* Each of the compounds tested was administered to the rats at 11 a.m. diestrus II.

CMA : Chlormadinone acetate

MAP : Medroxyprogesterone acetate 
Table 3. Effects of androgens, estrogens and corticoid on the spontaneous ovulation in rats

\begin{tabular}{|c|c|c|c|c|}
\hline Compound* & $\begin{array}{c}\text { Route of } \\
\text { administration }\end{array}$ & $\begin{array}{l}\text { Dose } \\
\text { (mg) }\end{array}$ & $\frac{\text { No. of rats ovulated }}{\text { No. of rats used }}$ & $\begin{array}{c}\text { Aver. No. of } \\
\text { ovulation per rat }\end{array}$ \\
\hline Testosterone propionate & Subc. & $\begin{array}{l}0.05 \\
0.5 \\
5.0\end{array}$ & $\begin{array}{l}5 / 5 \\
2 / 5 \\
0 / 5\end{array}$ & $\begin{array}{r}12.6 \\
6.8 \\
0\end{array}$ \\
\hline Methyltestosterone & Oral & $\begin{array}{r}0.5 \\
5.0 \\
10.0\end{array}$ & $\begin{array}{l}4 / 5 \\
4 / 5 \\
0 / 5\end{array}$ & $\begin{array}{r}7.8 \\
9.6 \\
0\end{array}$ \\
\hline Estradiol-17 $\beta$ & Subc. & $\begin{array}{l}5.0 \times 10^{-5} \\
5.0 \times 10^{-4} \\
5.0 \times 10^{-3}\end{array}$ & $\begin{array}{l}5 / 5 \\
5 / 5 \\
5 / 5\end{array}$ & $\begin{array}{r}9.0 \\
10.4 \\
13.6\end{array}$ \\
\hline \multirow[t]{2}{*}{ Mestranol } & Subc. & $\begin{array}{l}2.5 \times 10^{-3} \\
2.5 \times 10^{-2} \\
5.0 \times 10^{-2}\end{array}$ & $\begin{array}{l}5 / 5 \\
5 / 5 \\
5 / 5\end{array}$ & $\begin{array}{r}10.2 \\
11.0 \\
8.8\end{array}$ \\
\hline & Oral & $\begin{array}{l}2.5 \times 10^{-3} \\
2.5 \times 10^{-2} \\
5.0 \times 10^{-2}\end{array}$ & $\begin{array}{l}5 / 5 \\
4 / 5 \\
5 / 5\end{array}$ & $\begin{array}{r}11.2 \\
7.8 \\
13.0\end{array}$ \\
\hline Corticosterone & Subc. & $\begin{array}{l}0.05 \\
0.5 \\
5.0\end{array}$ & $\begin{array}{l}4 / 4 \\
5 / 5 \\
5 / 5\end{array}$ & $\begin{array}{l}10.3 \\
12.0 \\
11.0 \\
\end{array}$ \\
\hline
\end{tabular}

* Each of the compounds was administered to the rats at 11 a.m. diestrus II.

day corresponding to the coming estrus as described in the previous report (Kobayashi et al., 1968). Ovulation inducing activities of several progestins were also examined by the method described previously (Kobayashi et al., 1969). Several synthetic progestins were injected subcutaneously $50 \mathrm{hr}$. after subcutaneous treatment with progesterone, $3 \mathrm{mg}$ per rat of which had been given at 11 a.m. on the day of diestrus II to induce approximately $48-\mathrm{hr}$. delay in ovulation. The animals were autopsied on the following morning (72 hr. after treatment with progesterone) to confirm the occurrence of ovulation by the presence of fresh ova in the oviducts.

The following trivial names were used: Chlormadinone acetate (CMA): $17 \alpha$-acetoxy-6-chloropregna-4,6-diene-3,20-dione; Medroxyprogesterone acetate (MAP): $17 \alpha$-acetoxy-6 $\alpha$-methylpregn-4-ene-3, 20-dione; Norethindrone; $17 \alpha$-ethynyl-17 $\beta$-hydroxyestr-4-en-3-one; Norethynodrel: $17 \alpha$-ethynyl-17 $\beta$ hydroxyestr-5(10)-en-3-one; Testosterone propionate: $17 \beta$-propionyloxy-androst-4-en-3-one; Methyltestosterone: $17 \alpha$-methyl-17 $\beta$-hydroxyandrost-4-en-3-one; Mestranol: $17 \alpha$-ethynyl-3-methoxyestra-1,3,5(10)- trien-17 $\beta$-ol.

\section{Results}

\section{1) Effects on spontaneous ovulation}

Various steroids including progestin, androgen, estrogen and corticosterone were administered subcutaneously or orally at $11 \mathrm{a} . \mathrm{m}$. on the day of diestrus II to investigate their effects on the spontaneous ovulation normally expected on the day of estrus. The data presented in Table 1 demonstrate that progesterone, CMA, MAP and norethindrone inhibit ovulation except norethynodrel. A minimum effective dose to suppress spontaneous ovulation by a single injection was $0.5 \mathrm{mg}$ per rat for MAP and norethindrone and $5 \mathrm{mg}$ per rat for progesterone and CMA. Partial inhibition of ovulation 
Table 4. Effects of progestational steroids on the progesterone-induced delay of ovulation in rats

\begin{tabular}{|c|c|c|c|}
\hline Compound* & $\begin{array}{l}\text { Dose } \\
(\mathrm{mg})\end{array}$ & $\frac{\text { No. of rats ovulated } * *}{\text { No. of rats used }}$ & $\begin{array}{c}\text { Aver. No. of ovulation } \\
\text { per rat }\end{array}$ \\
\hline- & - & $0 / 5$ & 0 \\
\hline Progesterone & 10.0 & $5 / 5$ & 12.2 \\
\hline C M A & 10.0 & $6 / 10$ & 4.2 \\
\hline M A P & 10.0 & $7 / 8$ & 8.3 \\
\hline Norethindrone & 10.0 & $5 / 5$ & 8.4 \\
\hline Norethynodrel & 10.0 & $0 / 5$ & 0 \\
\hline
\end{tabular}

* Each of the compounds tested was injected subcutaneously $50 \mathrm{hrs}$. after the initial treatment with progesterone ( $3 \mathrm{mg} /$ rat subcutaneously at 11 a.m. diestrus II).

** Rats were autopsied $72 \mathrm{hrs}$. after the initial progesterone treatment.

CMA : Chlormadinone acetate

MAP : Medroxyprogesterone acetate

Table 5. Effects of several progesterone metabolites on the progesterone-induced delay of ovulation in rats

\begin{tabular}{lcr}
\hline \multicolumn{1}{c}{ Compound $*$} & No. of rats ovulated $* *$ & $\begin{array}{c}\text { No. of ova per } \\
\text { ovulated rat }\end{array}$ \\
\cline { 2 - 3 } & No. of rats used & 2.0 \\
\hline $20 \alpha$-Hydroxypregn-4-en-3-one & $1 / 5$ & 10.3 \\
$20 \beta$-Hydroxypregn-4-en-3-one & $3 / 10$ & 10.0 \\
$5 \beta$-Pregnane-3 $\alpha, 20 \alpha$-diol & $1 / 5$ & 9.0 \\
$3 \beta$-Hydroxy-5 $\beta$-pregnan-20-one & $1 / 5$ & 13.0 \\
$17 \alpha$-Hydroxypregn-4-ene-3,20-dione & $1 / 5$ & 16.0 \\
$11 \alpha$-Hydroxypregn-4-ene-3,20-dione & $1 / 5$ & 0 \\
$11 \beta$-Hydroxypregn-4-ene-3,20-dione & $0 / 5$ & 6.0 \\
Pregn-4-ene-3,11,20-trione & $3 / 10$ & 0 \\
$6 \beta$-Hydroxypregn-4-ene-3,20-dione & $0 / 5$ & 0 \\
\hline
\end{tabular}

* Each of the compounds tested was injected subcutaneously $50 \mathrm{hrs}$. after the initial treatment with progesterone $(3 \mathrm{mg} /$ rat subcutaneously at 11 a.m. diestrus II).

** Rats were autopsied 72 hrs. after the initial progesterone treatment.

was observed in the rats receiving $0.05 \mathrm{mg}$ per rat of MAP or norethindrone and in the rats injected with $0.5 \mathrm{mg}$ per rat of progesterone or CMA.

Effects of these steroids administered orally at 11 a.m. diestrus II on spontaneous ovulation are presented in Table 2. CMA and MAP completely suppressed ovulation at the dosage of $5 \mathrm{mg}$ per rat. On the other hand, progesterone and norethindrone given orally failed to inhibit ovulation even at the dosage of $10 \mathrm{mg}$ per rat, although both of them inhibited ovulation when injected subcutaneously. Norethynodrel did not inhibit spontaneous ovula- tion by oral route at the dosages up to $10 \mathrm{mg}$ per rat. Partial but nearly complete inhibition of ovulation was obtained in the rats receiving $\mathrm{MAP}$ at the dosage of $0.5 \mathrm{mg}$ per rat.

Effects of two androgens, two estrogens and corticosterone administered subcutaneously or orally at 11 a.m. diestrus II on spontaneous ovulation are presented in Table 3. Either testosterone propionate injected subcutaneously or methyltestosterone administered orally produced a complete inhibition of spontaneous ovulation at the dosages of 5 and $10 \mathrm{mg}$ per rat, respectively. Partial inhibition of ovulation was obtained in the rats receiving $0.5 \mathrm{mg}$ per rat of 
testosterone propionate. Subcutaneous administration of estradiol- $17 \beta$ or corticosterone, however, did not inhibit ovulation àt any dosage given in this experiment. Mestranol was also ineffective in this test by subcutaneous or oral administration.

In the above experiments, vaginal smears taken at the time of autopsy of the rats whose ovulation was inhibited indicated a mixture of leucocytes and nucleated cells, whereas only cornified cells were found in the vaginal smears of the rats which ovulated.

\section{2) Effects on delayed ovulation}

The effects of progestational steroids on the 48-hr. delay in ovulation caused by $3 \mathrm{mg}$ of progesterone, which was administered at 11 a.m. on the day of diestrus II, are presented in Table 4. The data clearly demonstrate that progesterone, MAP and norethindrone given subcutaneously $50 \mathrm{hr}$. after the initial treatment with progesterone at the dosage of $10 \mathrm{mg}$ per rat induce ovulation $24 \mathrm{hr}$. earlier than the controls receiving the initial progesterone alone. Of the rats receiving $10 \mathrm{mg}$ per rat of CMA, 6 out of 10 rats also demonstrated the restoration of delayed ovulation in $24 \mathrm{hr}$. Norethynodrel, however, failed to restore the delayed ovulation at the same dosage. The activities of several pregnane derivatives to restore the delay in ovulation were investigated by the subcutaneous injection of $10 \mathrm{mg}$ per rat. The results shown in Table 5 indicate that none of the compounds administered $50 \mathrm{hr}$. after the initial progesterone treatment produced, in $100 \%$, the 24-hr. restoration in the 48-hr. delay in ovulation. Less than $30 \%$ effectiveness, which was shown by most of the compounds tested, may be doubtful, since approximately $10 \%$ of the controls showed 24-hr. delay instead of 48-hr. delay in ovulation as indicated by the previous paper (Kobayashi et al., 1969).

\section{Discussion}

The present experiment demonstrates that, when administered at 11 a.m. on the day of diestrus II, a pregnane type of synthetic progestins such as CMA and MAP inhibit spontaneous ovulation in the rats either by subcutaneous or by oral administration, whereas a 19-nor type of progestins, norethindrone and norethynodrel are quite inactive by oral route of administration, although norethindrone is markedly active when given subcutaneously. Since either CMA or MAP has a potent progestational activity in the Clauberg rabbits (Brennan and Kraay, 1963; Miyake et al., 1965), it is assumed that ovulation inhibiting activity of a pregnane type of progestins may be correlated with progestational activity of the compounds. However, norethindrone, which has only onetenth the activity of progesterone in the progestational activity test by subcutaneous injection (Miyake and Pincus, 1958), manifested remarkable inhibition of ovulation, and norethindrone and norethynodrel, both of which have a potent progestational activity by oral route (Miyake and Pincus, 1958), failed to inhibit ovulation by the same route. This indicates that ovulation inhibiting activities of synthetic progestins, in general, do not necessarily correlate with their progestational activities. Kincl and Dorfman (1963a) also reported that there is no correlation between the ovulation inhibiting activity and progestational activity of steroid in the rabbits. The ability of progesterone and a certain 19-nor type of progestin to inhibit postcoital ovulation in the rabbits has been reported frequently (Pincus et al., 1956; Rock et al., 1956; Kincl and Dorfman, 1963a and b). However, it is also known that the treatment with norethynodrel at the dosage level sufficient to cause sterility does not consistently suppress ovulation in spontaneous ovulator as evidenced by the presence of corpora lutea in the ovary at autopsy (Pincus et al., 1956; Saunders, 1958; Holmes and Mandl, 1962). This was confirmed by the fact in the present study that norethynodrel given by a single administration on the day of diestrus II did not inhibit spontaneous ovulation at all either by subcutaneous or by oral adminis- 
tration. Norethindrone was effective to inhibit ovulation by subcutaneous injection but not effective by oral administration. It is speculated from these results that a 19-nor type of progestins administered orally lose the ability to inhibit neural mechanism(s) concerning the secretion of gonadotropin, which stimulates estrogen secretion on the afternoon of diestrus II, immediately after passing through the liver, but the steroid still remains or even strengthens the activity to induce progestational proliferation in the uterine endometrium during or after metabolic degeneration in the liver.

The evidence has been accumulated that progesterone has a biphasic effect, stimulation and inhibition, on the release of $\mathrm{LH}$ and subsequent ovulation (Everett, 1948; Sawyer and Everett, 1959; McCormack and Meyer, 1965; Kawakami and Sawyer, 1967; Caligaris et al., 1968; Kobayashi et al., 1969). The present study demonstrates that not only progesterone but also two synthetic progestins, MAP and norethindrone, have a strong activity to restore delayed ovulation when administered subcutaneously $50 \mathrm{hr}$. after the initial treatment with progesterone. CMA also shows a similar property but is slightly less active than MAP and norethindrone. These results indicate that in addition to progesterone some of the synthetic progestins have an ability to stimulate neural mechanism(s) regulating LH release. Kawakami and Sawyer (1967) demonstrated that either norethindrone or norethynodrel gives a similar effect on the thresholds of EEG arousal and afterreaction responses in the rabbit. This does not agree with the results obtained in the present study, because norethindrone has a biphasic effect on the release of LH but norethynodrel does not show any effect on LH release in the rat. Hilliard et al. (1967) reported that $20 \alpha$-hydroxypregn-4-en-3one $(20 \alpha-\mathrm{OH}-\mathrm{P})$ acts as a stimulating agent to prolong and heighten $\mathrm{LH}$ release in mated rabbits. This differs from the result obtained in this study, because $20 \alpha-\mathrm{OH}-\mathrm{P}$ has no ability to restore delayed ovulation. It is considered, therefore, that there is a species difference on the action of progestin to stimulate neural mechanism(s) regulating the release of LH. It is also suggested that a stimulatory action of synthetic progestin on LH release does not correlate with progestational action of the compound, because the restoration of delayed ovulation did not occur in the rats administered norethynodrel, which has a progestational action in the Clauberg assay (Brennan and Kraay, 1963; Miyake et al., 1965).

It is concluded that orally active progestational steroids, especially a pregnane type of progestins, have a biphasic action, inhibition and facilitation, on the neural mechanism(s) regulating the release of $\mathrm{LH}$ and subsequent ovulation when given subcutaneously or orally to the rat. 19-Norsteroids, norethindrone and norethynodrel, however, have no such an oral effectiveness on the ovulation control mechanism(s) in the rat in spite of their oral activities to cause glandular proliferation in the rabbit endometrium. $20 \alpha-\mathrm{OH}-\mathrm{P}$, the secretory amount of which is greater than that of progesterone in the rat ovary, has no progesterone-like activity to facilitate ovulation in the ovulation-delayed rat. Pregnandiol and other hydroxylated or oxygenated metabolites of progesterone also appear to be not active as progesterone. Beside progesterone, testosterone propionate given subcutaneously and methyltestosterone given orally are active to inhibit rat spontaneous ovulation when administered on diestrus II, while estradiol, mestranol and corticosterone are quite inactive by the injection on the day of diestrus II.

\section{References}

Brennan, D. M. and R. J. Kraay (1963). Acta Endocrinol. (Kbh) 44, 367.

Caligaris, L., J. J. Astrada and S. Taleisnik (1968). Ibid. 59, 177.

Everett, J. W. (1948). Endocrinology 43, 198.

Hilliard, J., R. Penardi and C. H. Sawyer (1967). Ibid. 80, 901 .

Holmes, R. L. and A. M. Mandl (1962). J. 
Endocrinol. 24, 497.

Kawakami, M. and C. H. Sawyer (1967). Endocrinology 80, 857.

Kincl, F. A. and R. I. Dorfman (1963a). Steroids 2, 521.

Kincl, F. A. and R. I. Dorfman (1963b). Acta Endocrinol. (Kbh) 62, Suppl. 73.

Kobayashi, F. and T. Miyake (1960). Ann. Rept. Shionogi Res. Lab. 10, 213.

Kobayashi, F., K. Hara and T. Miyake (1968). Endocrinol. Japon. 15, 313.

Kobayashi, F., K. Hara and T. Miyake (1969). Ibid. 16, 251.

McCormack, C. E. and R. K. Meyer (1965). Fertil. Steril. 16, 384.
Miyake, T. and G.Pincus (1958). Endocrinology 63,816 .

Miyake, T., F. Kobayashi, K. Horibe, E. Itoga, H. Kakushi, Y. Nomura, M. Kadowaki, K. Odaguchi, K. Hara, T. Furukawa and M. Ide (1965). Folia Endocrinol. Japon. 41, 1079.

Pincus, G., M. C. Chang, M. X. Zarrow, E. S. E. Hafez and A. Merill (1956). Endocrinology 59, 695.

Rock, J., G. Pincus and C. R. Garsia (1956). Sciences 124, 891.

Saunders, F. J. (1958). Endocrinology 63, 566.

Sawyer, C. H. and J. W. Everett (1959). Ibid. 65, 644 . 